\title{
Zhivaia Starina
}

\author{
M.V. Akhmetova \\ State Center for Russian Folklore \\ Moscow, Russia
}

The Russian journal Zhivaia Starina [Living Antiquity] continues the activity of the journal of the same name that had been published by the Russian Geographical Society in 1890-1917. The renewal of its publication was undertaken in 1994 by the State Center of the Republic for Russian Folklore.

The main concerns of Zhivaia Starina are the folklore and folk culture of Russians and other peoples in the territory of Russia and also of other Slavic and neighboring peoples. The journal publishes articles on the theory and language of folklore, on the history of folklore studies, on the genres of folklore, on rites and the folk calendar, on folk beliefs, and on folk art and crafts. On the pages of Zhivaia Starina one can find field research materials and archival materials from fieldwork in various regions of the Slavic world as, reviews of books on Russian and Slavic folklore, and chronicles of conferences on folklore and folk culture. This report provides an overview of the main topics covered and issues addressed in the papers published in Zhivaia Starina in 2013.

Volume 1 (2013) opens with a section on the aspects of folk performance traditions: repertoire, the process of performance, performance mastery, and the reception of folklore in art. N.A. Krinichnaia considers asides and commentaries of the bylina [epic] singers from Zaonezhie (Republic of Karelia). Three other articles deal with the song-performance traditions of the Cossacks: N.Iu. Danchenkova analyzes the activities of the Russian choirmaster S.A. Zharov and his Choir of Don Cossacks; T.S. Rudichenko offers an overview of the history of the Cossack choirs from the 18th century to the present day; T.B. Dianova published the songs she recorded in a Cossack village on the Don.

The next section comprises articles and publications related to mythological (mainly demonological) characters. A.V. Pigin published a handwritten religious poem from the early 20th century about the "repenting" demon Zerefer. V.V. Vinogradov considers the folkloric motif of putting a pot on one's head in order to protect oneself from evil forces (the pot acts as a symbolic "double" of the head and crumbles under the blow of the demonological character, while its bearer suffers no harm). S.V. Kuchepatova offers an edition of the mythological stories recorded from Russian Germans of Kaliningrad region. Other topics in this section include the beliefs about "walking dead" in Polessie (E.E. Levkevskaia), notions about demonological characters in Ivanovo (O.V. Gordenko) and Yaroslavl regions (V.V. Zaporozhec), and the conception of the so-called dobrohozhie, Belarusian mythological characters that bestow magical knowledge on people who help them (G.I. Lopatin).

The section "From the History of Scholarship" comprises articles by T.A. Titova and M.V. Viatchina summarizing ethnographic photographs of everyday life and rituals of the Chuvash people taken at the beginning of the 20th century by Gurii Komissarov. In the "Exhibitions" section, S.F. Mahrachev introduces readers to the ethnographic museum at the University of Tambov.

Volume 2 (2013) is devoted to folk costume in different traditions: Russian (S.V. Prosina on the wedding dress in the Vladimir Province/Region in the first half of the 20th century), Bulgarian (S.V. Dmitrieva and O.V. Karpova on the wedding dress of the 19th century and A.P. 
Iakimova on the woman's prestilka [apron]), and Central Asian (T.G. Emelianenko on the dress of Bukharan Jews).

Volume 3 (2013) is divided into two major sections. The first one is devoted to the problems of field research. Iu.A. Novikov published his recollections of his first expeditions to Zaonezhie in the 1950s. L.I. Ivanova presents an overview of the field studies of folklore and traditions of Liudik Karels. Zh. I. Surkova considers variations of fairy-tale texts recorded from one informant at different times.

The second section, "Folklore and Ethnographic Mosaic," deals with folk legends. I.A. Bessonov examines how fictional country Belaia Arapiia [The White Land of the Dark People], notions of which date back to the military action of Ottoman forces against insurgent Egypt in 1833, in which Russia took part. He reinterprets the legend as an example of an eschatological enemy in the popular imagination of the mid-20th century, while being represented as a happy utopia and later evolving into an expression for pipe dream in Russian literature and journalism. A.R. Zudin examines motifs of etiological legends of Nekrasov Cossacks. N.R. Oinotkinova addresses the reception of biblical narratives in the folklore of Telengits, an Altaic people Christianized in the last third of the 19th century.

Volume 4 (2013) opens with the section "Folklore and Ethnography in Manuscript Sources," which comprises research papers and publication of new material pertaining to the reflection of traditional culture in manuscripts of different genres and styles. Two articles deal with the manuscripts from the archive of G.F. Beloshitskaia (the village of Kandakaksha, Murmansk Region), who maintains her family archive and collects her relatives' recollections for a family chronicle. I.A. Razumova presents a comprehensive description of the chronicle by Beloshitskaia, while O.V. Zmeeva published materials on children's games and pastimes from Beloshitskaia's archive. O.V. Buivolova and L.R. Kim analyze a manuscript collection of folkloric texts belonging to a woman living in a village on the Don and compare the contents of written texts with oral interviews recorded from the author of the manuscript. V.P. Ershov presents the interesting personal records of Mr. Ananin, a cooper, containing data on rural life and traditions of a Karelian village in the 1930s. M.S. Popova prepared an edition of poetic texts (including folklorized literary works) from young girls' sketch-books of the late $19^{\text {th }}$ and early $20^{\text {th }}$ centuries.

The next section is devoted to the symbolism and functions of objects. O.A. Suleimanova considers different types of objects that perform memorial functions in family culture. O.V. Gordienko describes a shepherd's drum that he discovered on an expedition to Zavolzhie (Nizhny Novgorod region). I.Iu. Vasiliev describes beliefs and magical practices connected with an exhibit of a village museum in Kuban, a Cuman stone baba [woman]. A.G. Kuleshov considers the variation of the motif of the rider-hero in different styles of Russian toy pottery.

Zhivaia Starina also acquaints readers with regional varieties of Slavic folklore. In 2013, the magazine published materials on the folklore and traditions of the Tambov (Volume 1), Kuban (Volume 2), and the Kaluga regions (Volume 3). The section devoted to the folklore of Tambov region deals with aspects of the folk calendar (T.V. Makhrachova on rituals associated with the holiday of Saints Kuzma and Demian); popular beliefs about the afterlife (a joint article by D.S. Ippolitova and T.V. Makhrachova); traditional medicine (D.N. Loskutova on images of fever in the folklore of Tambov peasants), and folk meteorology (A.A. Chemerchova on rites to stop a hailstorm).

The section on the folk culture of Kuban, prepared by the staff of the Kuban Cossack Choir comprises materials recorded from Lipovan Old Believers (a paper by A.A. Zudin on healing 
charms) and articles on the folklore and traditions of the Cossacks. O.V. Matveev devoted his article to folk toponymy of the Kuban Cossacks; I.Iu. Vasilyev presented materials on oral history (narratives of elder Kuban Cossack villagers about the Civil War); S.A. Zhiganova focuses on the representation of the ritual space of the Kuban wedding in wedding songs; O.Iu. Skvortsova described folk weaving techniques; V.V. Voronin presented materials for the ethnocultural dictionary of Kuban relating to such a significant object of the Cossack culture as a cap.

Papers on the folklore of Kaluga region deal mainly with calendar festivals: ice-hill sledding and horseback riding on Shrovetide (T.V. Soboleva); rituals associated with the day of St. Peter and Paul (A.A. Ivanova); Yuletide excess, divination and mumming (B.A. Gasanov). A joint paper by A.A. Ivanova and Ia.Iu. Solovieva analyses recollections of peasants about the life of the folk tradition during the World War II, when part of the Kaluga region was occupied by the Nazis. A.F. Balashova documented stories about mermaids (rusalki) collected in the region.

Several sections were devoted to the traditional culture of ethnic diasporas in the postSoviet space. Employees of the St. Petersburg Museum of Anthropology and Ethnology (Kunstkammer) presented materials collected from Albanian immigrants residing in Budzhak and Northern Azov (Volume 3). The papers were devoted to Albanian family rites, including the wedding ceremony and problems of interethnic marriages (A.A. Novik), birth rites (A.S. Dugushina), and funeral and memorial rites (D.S. Ermolin). Volume 4 also contains materials of an expedition of the Center for Typological and Semiotic Folklore Studies (Moscow) to Ukrainians who settled in the Saratov region in the $18^{\text {th }}$ century. Saratov Ukrainian tradition is represented by Yuletide and Easter rites (E.E. Levkevskaia), folk legends based on the Old and New Testament narratives (D.I. Antonov), demonological beliefs (A.I. Sheveleva), and funeral rites (N.V. Koptev).

In 2013 Zhivaia Starina also provided coverage of the Third All-Russian Congress of Folklorists organized by the State Center of the Republic for Russian Folklore in February 2014. Volume 2 featured the results of a discussion on the current state of affairs in folkloristics, in which authors of the journal working in academic centers in Moscow and Saint Petersburg (A.S. Kargin, S.Iu. Nekliudov, T.G. Ivanova, M.A. Lobanov, and A.K. Baiburin) took part. Researchers discussed the field of contemporary folklore studies as well as less prominent (if not entirely forgotten) folkloristic subdisciplines and the problems of teaching folklore.

Volume 4 devoted an entire section to the upcoming congress. The papers it comprised were mostly devoted to the problem of minor genres. L.N. Vinogradova posed a number of important questions about the criteria for inclusion of various clichés into the category of minor folk genres and analyzed various types of ritual-magical, interpretative, and etiquette formulas in detail. O.E. Frolova considered the depiction of the category of time in proverbs, while A.A. Gavrylenko described the use of proverbs in the speech of an informant. G.I. Lopatin, while focusing on a single Belarusian informant, presented folk semantic interpretations of various clichés. G.I. Romanii analyzed Russian formulaic exclamations accompanying children's games and their regional variations in the post-Soviet space.

Zhivaia Starina also covered the XV International Congress of Slavic Studies (Minsk, August 2013). The section entitled "Slavic Mosaic" (Voluyme 2) opened with a review of papers presented at past congresses (S.M. Tolstaia and O.V. Belova), and included articles on various aspects of folk culture of the Slavic world. V.V. Napolskikh turned to the local festival Bodun (Viatka Region) and speculated about the connection of its name with the Ancient Russian word $b($ ") $d y n$ " found in the life of Saint Olga; in his opinion, the word originally denoted a pre- 
Christian funeral and memorial rite of which the Viatka festival is a relic. A.A. Plotnikova described legendary and demonological belief narratives recorded from Bosnian Muslims (the village of Umoliani) reflecting an ancient mythological worldview. N.V. Serbina analyzed the musical features of later Ukrainian lyrical songs and speculated about their origins.

The regular "Expeditions" section in 2013 acquainted readers with field materials recorded from Russians (of the Perm region, S.Iu. Korolieva, E.M. Chetina and I.Iu. Rogotneva on folk funeral prayers; and of the Vladimir region, eschatological narratives prepared by A.D. Sokolova and I.A. Nikolaiev in Volume 1; see also texts of various genres from the Rostov region by O.V. Belova in Volume 2) and from ethnic minorities of Russian Federation, including the Komi (materials on folk calendar presented by L.S. Lobanova and A.N. Rassykhaeva) and Altaic people (K.E. Rozova on epic songs, folk festivals, and religious beliefs).

D.S. Nikolaev, Translator 
